\title{
Ekmek Mayası Yan Ürününün Etlik Piliçlerin Performans ve Kesim Özellikleri Üzerine Etkileri
}

\author{
Goray ERENER ${ }^{1}$ \\ Nuh OCAK' Ergin OZTURK' \\ Aslı OZDAŞ'
}

Geliş Tarihi: 01.02.2001

\begin{abstract}
Ozek: Bu çalişma soya küspesinin \%50'si ve \%100'0 yerine katılan ekmek mayası yan ürününün (EMYÜ) etlik pliliçlerin canlı ağirlik, canlı ağırlık artısı, yem tüketimi, yem değeriendirme sayısi ve bazı kesim özellikleri üzerine olan etkilerini Delirlemek amacıyla yapilmiştir. Denemede toplam 450 adet günlük Ross 308 erkek etlik civciv kullanılmıştır. Çalışmada herbirinde 150 adet günlük civciv bulunan (her tekerrür için 50 hayvan) 3 grup oluşturulmuştur. Altı haftalık deneme sonunda deneme sonu canlı ağırlığı $(2328 \pm 27,2169 \pm 55,1754 \pm 35 \mathrm{~g})$, canlı ağırlik artışı $(2285 \pm 27,2126 . \pm 55,1711 \pm 35 \mathrm{~g})$. yem değeriendirme sayısı $(1.93 \pm 0.03,2.12 \pm 0.04,2.58 \pm 0.09)$ ve karkas ağılığı $(1658 \pm 15,1540 \pm 37,1201 \pm 20 \mathrm{~g})$ bakımından gruplar arasinda çok önemli $(P<0.01)$; karkas randımanı $(\% 71.21 \pm 0.63,71.05 \pm 0.94,68.17 \pm 0.90)$ ve yenilebilir iç organlar bakimindan $(\% 4.17 \pm 0.08,4.11 \pm 0.09,5.06 \pm 0.50)$ önemli $(P<0.05)$ farkliliklar bulunmuştur. Yem toketimi $(4406 \pm 87,4513 \pm 30$, $4408 \pm 70)$, sindirim sistemi ağırliğı $(184.1 \pm 10,183.7 \pm 8,163.4 \pm 7 \mathrm{~g})$, sindirim sistemi uzunluğu $(231.3 \pm 12,223.8 \pm 5,220,6 \pm 9$ $\mathrm{cm}$ ) ve abdominal yağ oranı (\%1.15 $\pm 0.08,1.07 \pm 0.12,1.07 \pm 0.08)$ bakımından gruplar arasında görulen farkiılı önemsiz bulunmuştur $(P>0.05)$. Sonuç olarak etllk pllic karmalarına soya küspesinin $\% 50$ 'si ve $\% 100$ 'o yerine EMYünuán kullanılmasının dönem sonu caniı ağıılıkiant, canlı ağırlık artışlan, yemn değerlendirme sayısı, karkas ağırlıklarını ve karkas randımanını olumsuz etkilediği saptanmıştır.
\end{abstract}

Anahtar Kelimeler: Etlik piliç, ekmek mayası yan ürünú, besi performansi, kesim özellikleri

\section{Effects of Baker's Yeast By-product on Performance and Slaughter Traits of Broilers}

\begin{abstract}
This study was carried out to determine the effects of rations containing 50 and $100 \%$ baker's yeast byproduct as a substitute for soybean meal on final live weight, live weight galn, feed efficiency ratio, feed consumption and some slaughter trait of broilers. In the study, 450 daily Ross 308 male broilers were used. They were divided into three groups each containing 150 broilers ( 50 males for each replication). At the end of the experiment ( 42 days), differences among the groups in terms of final live weight $(2328 \pm 27,2169 \pm 55,1754 \pm 35 \mathrm{~g})$; live weight gain $(2285 \pm 27,2126 . \pm 55$, $1711 \pm 35 \mathrm{~g})$, feed efficiency ratio $(1.93 \pm 0.03,2.12 \pm 0.04,2.58 \pm 0.09)$ and carcass weight $(1658 \pm 15,1540 \pm 37,1201 \pm 20 \mathrm{~g})$ were statistically significant $(P<0.01)$. The differences concerning dressing percentage $(71.21 \pm 0.63,71.05 \pm 0.94$, $68.17 \pm 0.90 \%)$ and edible viscera ratio $(4.17 \pm 0.08,4.11 \pm 0.09,5.06 \pm 0.50 \%)$ were statistically significant $(P<0.05)$. There were no differences $(P>0.05)$ among the treatments in terms of feed consumption $(4406 \pm 87,4513 \pm 30,4408 \pm 70 \mathrm{~g})$, gut weight $(184.1 \pm 10,183.7 \pm 8,163.4 \pm 7 \mathrm{~g})$, gut length $(231.3 \pm 12.5,223.8 \pm 5.0,220.6 \pm 9 \mathrm{~cm})$ and abdominal fat ratio $(1.15 \pm 0.08$, $1.07 \pm 0.12,1.07 \pm 0.08 \%$ ). It is concluded that the addition of $50 \%$ and $100 \%$ baker's yeast by-product as a substitute for soybean meal to broiler rations had negative effects on final live weight, live weight gain, feed efficiency ratio, carcass weight and dressing percentage.
\end{abstract}

Key Words: Broiler, Baker's yeast by-product, fattening performance, slaughter traits

\section{Giriş}

Kanatlı hayvan yetiștiriciliğinde yem masrafları uron masraflarının \%60-70'ini hatta bazen \%80'ini oluşturmaktadir. Üretim maliyetini doşarmenin en kolay yolu ise yem masraflarının azaitılmasidır. $\mathrm{Bu}$ ya karmalarda kullanılan hammaddelerin daha yoğun bir şekilde üretilmesine ya da alternatif hammaddelerin bulunup kullanılmasına bağiıdır. Ölkemiz karma yem sanayi gereksinim duyduğu yağlı tohum küspelerinden soya küspesinin \%70-80'ini ithal yoluyla karşılarken, pamuk tohumu küspesi ve ayçiçeği tohumu küspesinin ise zaman zaman değişmekle birlikte hemen hemen tamamını $(\% 90)$ iç piyasalardan karşılamaktadır ( Koca, 1998 ). Kanatlı karmalarının vazgeçilmez hammadde kaynaklarindan olan soya küspesinin ülkemizde yetersiz üretilmesi bu hammaddenin yoksek oranlarda ithal edilmesine ve dolayısıyla da fiyatının yûkselmesine yol açmaktadır. Böyle durumlarda ise yem ureticisi açığı daha düşük kalitedeki küspelerle kapatma yoluna gitmektedir. Ancak son yillarda maya, alg ve bakterilerlerden oluşan tek hücre proteinlerinin (THP) ăretimi ve yem olarak değerlendirilmesi konusunda kapsamlı araştırmalar yapılmıştır. Bunların sayesinde bir çok ülkede çeşitli mikroorganizmalar kullanılarak birçok substrattan THP aretimi oldukça yaygınlaşmıştır (Öztürk ve Ózen, 1994).

Ekmek mayası (Saccharomyces cerevisiae) ve/veya yem maddesi olarak kullanilan mayalar protein, esansiyel amino asitler ve enerji içeriğinin yağli tohum küspelerine 
benzerliği açısından soya kospesine alternatif olma konusunda boyok bir potansiyele sahiptir (Yalçin ve ark.. 1998; Yalçın ve Önol, 1999). Saccharomyces cerevisiae tura mayalarin saf formlannin etilk piliçlerde saya köspesi yerine kullanımı lle ilgili çalışmalardan (Atay ve Erdem, 1972; Valdivie, 1975; Sarı, 1976; Sarı ve ark, 1978; Gunzel ve Vogt, 1982) olumlu sonuçlar alinmıştır.

Ekmek mayasınin etlik piliç (Yalçin ve ark, 1993) ve yumurta tavuğu karmalarına (Yalçin ve Onol, 1998) $\% 10$ a kadar, bildircin karmalarina \%15 duzeyine kadar (Şehu ve ark, 1997) ve yine etlik piliçlerde (Yalcin ve ark., 1998) et kalitesine olumsuz etkisi olmadan \%20'ye kadar katılabileceğini bildirmişlerdir. Ekmek mayasının aratimi sırasında isletmenin kendi beliflediği standartlara uymayan (rengi, kokusu, maya guco olumsuzluklari) ve elek Osto olarak tanimianan kuru ekmek mayasi yan üränä elde edilmektedir. Bu äün ekmek yapıminda kullanilmadığından yem fabrikalarina satilarak değerlendirilmesi yoluna gidilmektedir. Uretim miktarı çeşitil faktorlere göre değișmekle birlikte yaklaşık 2000 ton duzeyine sikabilmektedit, Ancak bu mayaların teknolo]lik ișlemlerde kullanildıktan sonra atilan atıklarınin (yan arönlerinin) kullanılabilirliği konusunda da araştırmalar yapilmaktadır (Oztôtk ve Ozen, 1994).

Bu çalışma, ekmek mayası olarak kullanilmayan (standart diși) yan ürünün (LC 2049) etlik piliçlerde soya kuspesinin yerine kullanilabilirliğinin belirlenmesi amacryla yapilmıştır.

\section{Materyal ve Yöntem}

Arastuma Ondokuz Mayıs Universitesi Ziraat Fakoltesi Dóner Sermaye Işletmesi Araştıma ve Uygulama Ciftligi'nde yourotolmuştor. Hayvan materyalini günlok yaștaki toplam 450 adet Ross 308 erkek etlik civcivler oluşturmuştur. Yem materyalini, birinci donem için (0-21. ganlet arasi) \%23 ham protein (HP) ve 3124 $\mathrm{kcal} \mathrm{ME} / \mathrm{kg}$, Ikinci donem için (21-42, gonler arasi) ise $\% 21 \mathrm{HP}$ ve $3200 \mathrm{kcal} \mathrm{ME} / \mathrm{kg}$ enerji içeren uç farkl karma oluşturmuștur (Çizelge 1). Karmalardan birinde (kontrol) soya Kuspesi (SK), diḡer ikisinde ise sırasıyla kontrol grubunda kullanılan SK'nin sağladığı proteinin \%50 ve \%100'ana karşılayacak kadar ekmek mayası yan arüno (EMYO) kullanilmiştir. EMYO'nun Akyildız (1984) tarafindan belirtildiği şekilde Weende analiz yôntemine gôre belirlenen bazı besin maddeleri İ̧erigi ile bazı katalog değerleri Çizelge 2'de verilmiştir. Karmaların yapisinda yer alan yemler Samsun Yem Sanayil A.Şden, EMYO ise Samsun Yem Sanayii A.S araciliğ lle Taşova Ozmaya A.Ş'den sağlanmışır.

Civcivler 3 muamele grubuna ağirliklari biribirine yakın olacak şekilde şansa bağlı olarak dağıtımışlardır. Gruplar, her birinde 50 hayvan olacak şekilde oç tekerrula olarak (her grup için toplam 150 adet) oluşturutmuştur. Deneme boyunca yem ve su serbest olarak verilmiştir. Canil agirlik (CA) ve yem toketimieri (VT) ve yem değerlendirme sayısı (YDS) deneme başı (0, g0n), 21. gün ve deneme sonunda ( 42 gän) belirienmiş, biomlet ise gönlak kaydedilmiştin. Her tekerrürden 3 hayvan olmak azere, her muameleden a hayvan (denemenin tamamı için 27 hayvan) kesilerek; karkas ağıriłğ, karkas randımani, abdominal yağ, yenilebilir iç organlar (kalp, karaciğer ve taşlık), sindirim sistemi ağırtiğı ve sindirim sistemi uzunluğu gibi ozellikler belirlenmiştir, Kesim oncesi hayvanlar 24 saat aç birakilmış ve sindirim sisteminin (yemek borusu, kursak, proventrikulus, tașlık, ince, kalın ve kör bağitsak) dolu ağırlığı tartılmiş ve uzuniluğu olçülmustür. Elde edilen verilerin varyans analizi SPSS paket programinda tesadof bloklari deneme düzenine göre yapilmıştır. Ortalamalar arasındaki farkliliklar ise Dunoan çoklu karşilaştırma testi ile belirlenmiștir.

\section{Bulgular ve Tartışma}

\section{Besi performansi sonuçlan!}

Etilk pillç karmalarında SK yerine EMYÜnün (özellikie \%100 dôzeyinde) kullanimasi, CA, CAA ve YDS uzerine olumsuz etkide bulunurken $(P<0,01)$ YT azerine ónemli bir etkisi olmamıştır ( $P>0.05$ ) (Çizelge 3 , Şekil $1 \mathrm{a}, \mathrm{b}$ ve Șekil $2 \mathrm{a}, \mathrm{b}$ ), lik 21 günde elde edilen CA bakımından 1. grup ve 2. grup arasinda istatistikj olarak farkilik bulunmazken ( $P>0.05$ ), bu iki grup ile 3 . grup arasinda çok onemii farklilik bulunmuștur ( $P<D D 1$ ). Deneme sonunda elde edilen CA bakımindan ise 1 . $(2328 \pm 27 \mathrm{~g})$ ve 2. $(2169 \pm 55 \mathrm{~g})$ gruplar arasinda önemil $\langle P<0.05)$, bu iki grup lle 3 grup $(1754 \pm 35 \mathrm{~g})$ arasinda çok onemli $(P<0.01)$ farkIlık bulunmuştur. Yirmibirinci günden deneme sanuna kadar veya deneme bașindan 42. gane kadar CAA bakımindan, 1. $(2285 \pm 27 \mathrm{~g})$ ve 2. $(2126 \pm 55 \mathrm{~g})$ grup arasinda onemili $(P<0.05)$, bu gruplar le 3. grup $(1711 \pm 35 \mathrm{~g})$ arasında çok onemli $(P<0.01)$ fark bulunmuştur. SK yerine \%50 dozeyinde EMYO, \%100 EMYO'ne göre yem taketimini daha fazla arttırmıştır. Deneme başindan deneme sonuna kadar kumulatif yem tüketimi 1, 2. ve 3 , grup için sırasıyla $4406 \pm 87,4513 \pm 30$ ve $4408 \pm 70 \mathrm{~g}$ olarak belirlenmiş ve gruplar arasindaki farklifğin istatistiki olarak onemsiz $(P>0.05)$ olduğu saptanmıştır. Ele alınan her uç dönemde de $(0-21,21-42$ ve 0-42. gunler arasi) SK yerine EMYÜ kullanilması yemden yararlanmanin doşmesine neden olmuştur. \%50 EMYU kullanilmasinin yemden yararlanmada neden olduğu daşaş 0-21 ve 0-42. günler için kontrol grubundan farksiz ( $P>0.05$ ) bulunurken, \%100 EMY0 kullanilmasinin neden olduğu duşaş ale alınan her dónemde çok onemli derecede daha yūksek bulunmuștur $(P<0,01)$ Sifır ve 42 . gunler arasi YDS sirasiyla $1.93 \pm 0,03,2.12 \pm 0.04$ ve $2.58 \pm 0.09$ olarak bulunmuștur.

Yalçın ve ark. (1993) etlik piliçlerde SK yerine ekmek mayası kullanilmasınin (ozellikle \%5 ve 10) CA ve YT'ni arttırdiği, yemden yararlanmayı ise daşarduğunö belirlemişlerdir Oztork ve Ozen (1994), şarapçilik artiğı maya tortusunun etlik piliclerde SK yerine \%2S'e kadar bile kullanilmayacağini bildirmişlerdir. Şehu ve ark. (1997) ise bildircin karmalarında SK yerine ekmek mayası kullanilmasinin CA ve CAA'ni dossardoguna YT'ni artırdığını ve yemden yararlanmayı ise kotolestirdiğini bildirmişlerdir, Çalışmalarda (Yalçın ve ark., 1993; Şehu ve ark. 1997) özellikle \%20 dozeyinde ekmek mayasi kullanıimasının ele alınan bzellikleri olumsuz etkilediḡi 
belirtilmiştir. Mevcut çalișmada da EMYÜ ekmek mayasına benzer sonuçlar vermiştir. Bu durum, THP'lerinin ortak ozelliklerinden olduğu gibi (Özen ve ark., 1981) EMYÖnün de standart bir ärän olmamasına ve noklek asit içeriğine bağlı olabilir. Bu çalışmada kullanilan EMYÜ'nün partikal boyutlan bakımından homojen bir materyal olmaması, hazırlanan karmaların partikuf yapısınin değişmesine neden olmuş olabilir, Nitekim EMYü'nün unsu yapısından dolayı ozeilikle 3. karmanin ince yapilı olmasına neden olmuştur. Bilindiği gib) tavuklar yemin fiziksel yapısı ve tanecik buyüklügünden etkilenmekte olup genellikle iri taneli yemleri seçme eğilimindedirler (Ozen,1989). Çok ince taneli yemler tavuklar tarafindan lezzetsiz bulunduklari için (Yeldan ve Çiftçi, 1993), tavuklar óncelikle iri taneli yemleri taketmekte, geriye ise toz formda karma kalmaktadır. Bu tür kamalar yem saçımını da arttırmaktadır. Diğer taraftan, karmalarda \%20 (Surdjiiska ve ark., 1987) veya \%40 (Virk ve ark, 1989) maya kullanımının, mayanin içerdiği yöksek nükleik asit (yaklaşık \%8) nedeniyle performansda gerilemelere yol açtığı belirlenmiştir. Bazı çalışmalarda ișe karmalarda kullanilan maya (örneğin melas ispirto mayası) seviyesinin \%15-20'nin uzerine çıkarılmasinın etilk piliçlerde su tuketimini yûkselttiăi, buna bağlı olarak sulu dışkı elde edildiği, bunun da rezorpsiyonu geriletmesı nedeniyle yemden yararlanma özerine olumsuz etkide bulunduğu belirtilmektedir (Ergül, 1975; Sarı ve ark, 1976). Mevcut çalışmada da literatürde (Yalçın ve ark., 1993; Şehu ve ark., 1997) belirttiği gibi 3. gruba ait hayvanlarin (tamamen EMYÜ kullanilan) daha sulu kıvamda dıskı ürettikleri ve altlık materyallerinin daha islak yapida olduklari gözlenmiștir. Karmalara artan duzeylerde EMYÜ ikamesinin performans azerinde görolen olumsuzluklarında, karmaların hazırlanmasında lisin, metiyonin dışında yeterince dikkate alinmayan esansiyel amino asitlerin eksiklikleri de etkili olmuş olabilir. Bu çalışmada karmalar bilgisayar programı lle hazirlanmış ve óncelikle lisin ve metiyonin gibi amino asitler dengelenmiş, arginin, treonin ve triptofan gib esansiyel amino asitler ise karmalar hazıriandiktan sonra hesaplama yolu ile bulunmuştur. Karmaların esansiyel amino asit içerikleri incelendiğinde bûyüme üzerinde önemli etkis/ bulunan bu amino asitlerden argininin ozzellikle 2. ve 3 gruplarda NRC (1984)'de belirtilen gereksinimi karşilayamadığı görülmektdir (Çizelge 1).

\section{Kesim özellikleri}

Etlik pilic karmalarında SK yerine EMYÜ kullamilması, karkas ağırlığı $(P<0.01)$ ve karkas randımanı $(P<0,05)$ üzerine olumsuz etkide bulunmuştur. Sindirim sistemi ağırìği ve uzunluğu lle karın yağı (CA'n!n \%'si) uzerine muamelelerin istatistiki olarak etkisi bulünmamasına rağmen, karmaya EMYO katılması, bu ozelliklerde sayısal olarak azalma meydana getirmiştir. CA'nin \%'si olarak hesaplanan yenilebilir iç organlar (kalp+karaciğer+taşlık) üzerine ise ónemfi $(P<0.05)$ etkisi bulunmuştur (Çizelge 4). Karkas ağırlığı (yenilebilir iç organlar hariç) $1 ., 2$ ve 3 , gruplar için sırasıyla $1658 \pm 15$, $1540 \pm 37$ ve $1201 \pm 20 \mathrm{~g}$ olarak belirlenmiş ve gruplar

Çizelge 1. Karmalarin hammadde ve besin maddeleri içerikleri*

\begin{tabular}{|c|c|c|c|c|c|c|}
\hline \multirow[b]{2}{*}{ Hammaddeler } & \multicolumn{3}{|c|}{$0-21$ günier } & \multicolumn{3}{|c|}{ 21-42.gunier } \\
\hline & 1 & 2 & 3 & 1 & 2 & 3 \\
\hline Misif & 50.970 & 53.344 & 54.730 & 55.600 & 56.900 & 59,300 \\
\hline Ekmek mayasi yan uraño & - & 12.792 & 26.010 & - & 10.000 & 20.000 \\
\hline Soya küspesi & 26.038 & 12.792 & - & 20.000 & 10.000 & $=$ \\
\hline Tam yağlı soya & 12.742 & 12.792 & 12174 & 15.000 & 15.000 & 14.000 \\
\hline Balık unu & 1,994 & 2.000 & 1.992 & 1,000 & 1.000 & 1,000 \\
\hline Et-kemik unu & 1.994 & 2.000 & 1.992 & 2.950 & 2.950 & 2.350 \\
\hline Bitkisel yag & 2,770 & 1.112 & - & 2.600 & 1.500 & 0.500 \\
\hline Mermer tozu & 1.662 & 1.668 & 1.660 & 1.500 & 1.510 & 1.540 \\
\hline Dikaisiyum fosfat & 0.886 & 0.390 & - & 0.550 & 0.150 & - \\
\hline Tuz & 0.300 & 0.300 & 0.300 & 0.300 & 0.300 & 0.300 \\
\hline Vitamin on karmas! ${ }^{1}$ & 0.250 & 0.250 & 0.250 & 0.250 & 0.250 & 0.250 \\
\hline Mineral on karması ${ }^{2}$ & 0.100 & 0.100 & 0.100 & 0.100 & 0.100 & 0.100 \\
\hline Antikoksidlyal & 0.018 & 0.018 & 0.018 & - & . & - \\
\hline Büyütrme faktöro & 0.110 & 0.110 & 0.110 & - & - & - \\
\hline $\mathrm{DL}$-metiyonin & 0.166 & 0.222 & 0.332 & 0,150 & 0.240 & 0.340 \\
\hline L-lisin & - & 0.110 & 0.332 & - & 0.100 & 0.320 \\
\hline \multicolumn{7}{|c|}{ Hesaplanmiș besin maddeleri } \\
\hline Ham protein, \% & 23.00 & 23.00 & 23.00 & 21.00 & 21.00 & 21.00 \\
\hline $\mathrm{ME}$, kcail/kg & 3124 & 3124 & 3124 & 3200 & 3200 & 3200 \\
\hline Kalsiyum, \% & 0.90 & 0.90 & 0.90 & 1.12 & 1.12 & $1: 12$ \\
\hline Yarar, Fosfor, \% & 0.47 & 0.47 & 0.47 & 0.45 & 0.45 & 0,45 \\
\hline Lisin, \% & 1.22 & 1.22 & 1.22 & 1.08 & 1.08 & 1.08 \\
\hline Metiyonin, \% & 0.54 & 0.54 & 0.54 & 0.49 & 0.49 & 0.49 \\
\hline Met + Sis., \% & 0.88 & 0.88 & 0.88 & 0.82 & 0.82 & 0.82 \\
\hline Arginin, \% & 1.53 & 1.38 & 1.23 & 1.42 & 1.31 & 1,15 \\
\hline Treonin.\% & 0.94 & 0.94 & 0.94 & 0.87 & 0.87 & 0.86 \\
\hline Triptofan,\% & 0.29 & 0.29 & 0,28 & 0.28 & 0.27 & 0.26 \\
\hline
\end{tabular}

*Karmalar, Sarnsun Yem San. ve Tic. A.Ş'de en dêşak maliyetil karma yem hazırlarna programı ("C MoonStar) ile hazırlanmıştır.

'. Her $1 \mathrm{~kg}$ 'da $6000000 \mathrm{lU}$ vitamin $A_{1} 800000 \mathrm{lU}$ vitarnin $\mathrm{D}_{3}, 8000 \mathrm{mg}$ vitarnin $\mathrm{E}, 2000 \mathrm{mg}$ vitarnin $\mathrm{K}_{3}, 1000 \mathrm{mg}$ vitamin $\mathrm{B}_{1}, 3000 \mathrm{mg}$ Vitamin $B_{2}, 2000 \mathrm{mg}$ vitamin $\mathrm{B}_{6}, 8 \mathrm{mg}$ vitamin $\mathrm{B}_{12}, 20000 \mathrm{mg}$ vitamin C, $4000 \mathrm{mg}$ Kalsiyum D-Pantotenat, $10000 \mathrm{mg}$ Niasin, $300 \mathrm{mg}$ Folik asit, $20 \mathrm{mg}$ Biotin, $400000 \mathrm{mg}$ Kolin klorid içermektedir.

2. Her I kg'da $80000 \mathrm{mg} \mathrm{Mn,} 30000 \mathrm{mg} \mathrm{Fe}, 60000 \mathrm{mg} \mathrm{Zn,} 5000 \mathrm{mg} \mathrm{Cu}, 500 \mathrm{mg} \mathrm{Co}, 2000 \mathrm{mg}$ l. $200 \mathrm{mg}$ Se içermektedir. 
Çizelge 2. Ekmek mayası yan ürününün (LC 2049) besin maddeleri içeriği

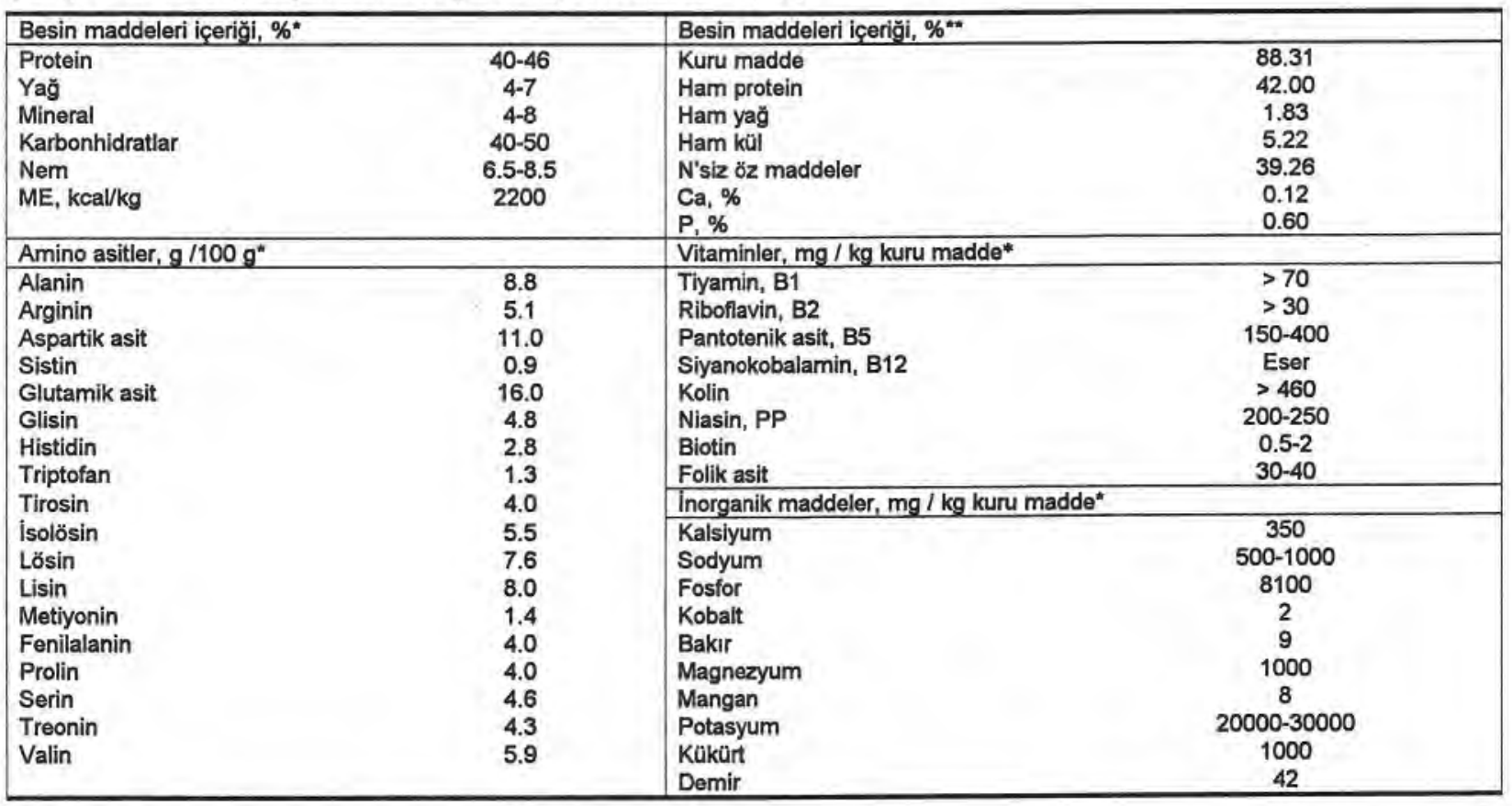

*Katalog değerleri

**Analiz ile belirlenen değerler

Çizelge 3. Etlik piliç karmalarında EMYÜ'nün CA, CAA, YT ve YDS üzerine etkileri

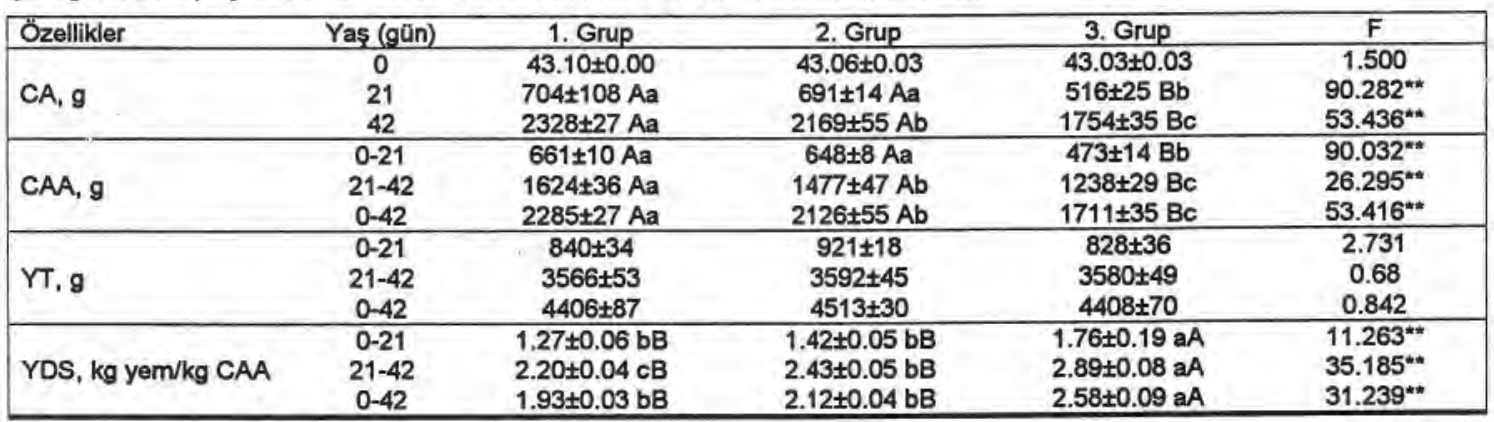

*(P<0.05), ** $(P<0.01)$

A, B; Aynı satırda ayrı harflerle gösterilen ortalamalar farkıdır $(P<0.01)$

a, b, c; Aynı satırda ayrı harflerle gösterilen ortalamalar farklıdır $(P<0.05)$

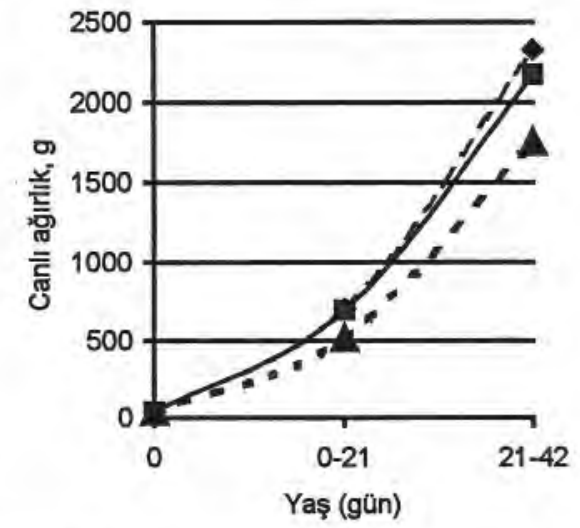

$-\diamond-1$. Grup -2 . Grup $=-1$. Grup

(a)

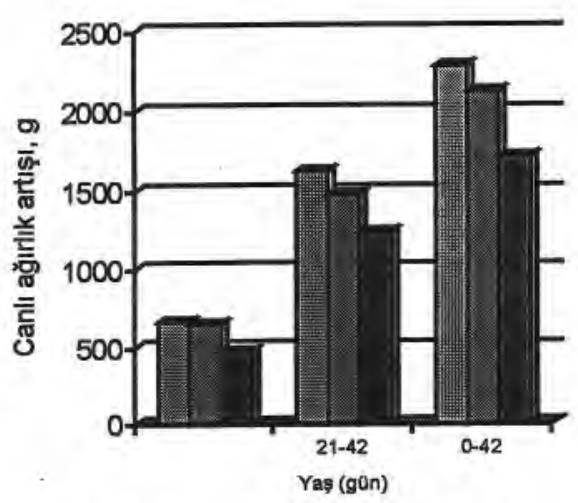

回1. Grup $\mathbf{2}$. Grup $\mathbf{3}$. Grup

(b)

Şekil 1. Etlik piliç karmalarında EMYÜ'nün kullanıımasının canlı ağırlık (a) ve canlı ağırıık artışı (b) üzerine etkisì 


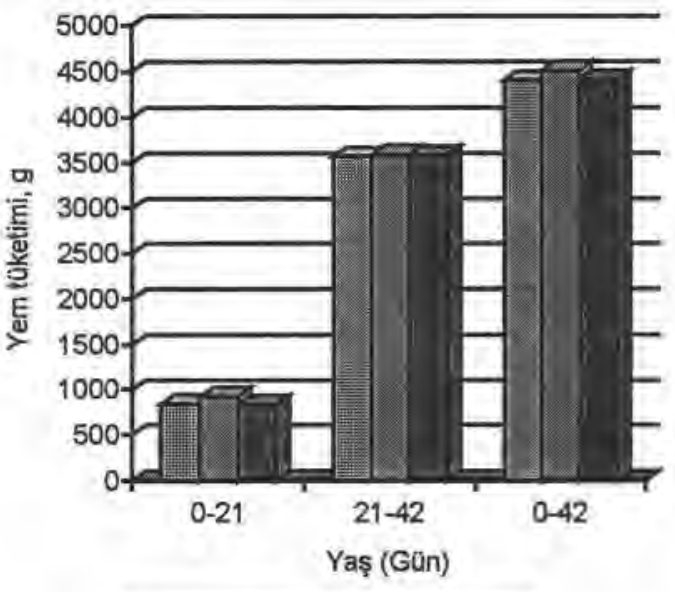

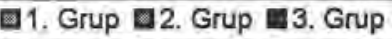

(a)

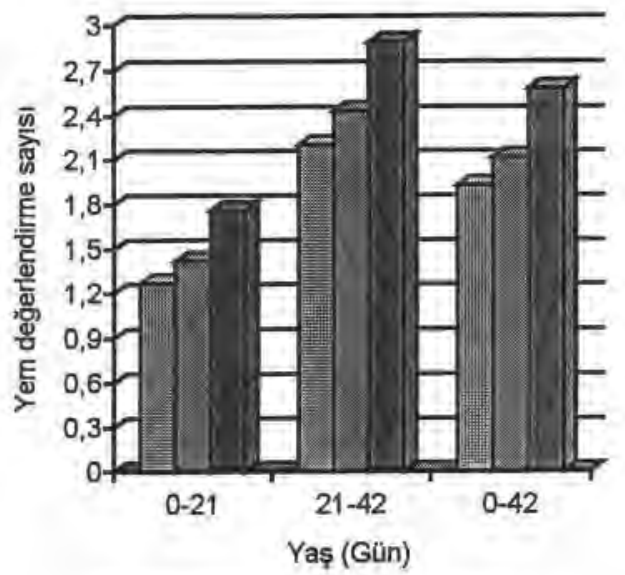

目1. Grup E2. Grup $\mathbf{m}$ 3. Grup

(b)

Şekil 2. EMYÜ'nün etlik piliçlerde yem tuketimi (a) ve yem değerlendirme sayısı (b) üzerine etkisi

Çizeige 4. Etlik piliç karmalarında EMYü'nün karkas ağırığı, karkas randımanı, sindirim sistemi ağırlığı, sindirim sistemi uzunluğu, abdominal yağ ve yenilebilir iç organlar üzerine etkileri

\begin{tabular}{|lcccc|}
\hline Ozellikler & 1. Grup & 2. Grup & 3. Grup & F \\
\hline Karkas ağırlığı, g & $1658 \pm 15 \mathrm{Aa}$ & $1540 \pm 37 \mathrm{Bb}$ & $1201 \pm 20 \mathrm{Cc}$ & $83.922^{* *}$ \\
Karkas randımanı, \% & $71.21 \pm 0.63 \mathrm{a}$ & $71.05 \pm 0.94 \mathrm{a}$ & $68.17 \pm 0.90 \mathrm{~b}$ & $4.164^{*}$ \\
Sindirim sistemi ağırlı̆ı, g & $184.1 \pm 10$ & $183.7 \pm 8$ & $163.4 \pm 7$ & 1.984 \\
Sindirim sistemi uzunluğu, cm & $231.3 \pm 12$ & $223.8 \pm 5$ & $220.6 \pm 9$ & 0.343 \\
Abdominal yağ, \% & $1.15 \pm 0.08$ & $1.07 \pm 0.12$ & $1.07 \pm 0.08$ & 0.203 \\
Yeniliebilir ic organlar, \% & $4.17 \pm 0.08 \mathrm{~b}$ & $4.11 \pm 0.09 \mathrm{~b}$ & $5.06 \pm 0.50 \mathrm{a}$ & $3.213^{*}$ \\
\hline
\end{tabular}

$*(P<0.05), * *(P<0.01)$.

$A, B, C ;$ Aynı satırda ayrı harflerie gösterilen ortalamalar farklıdır $(P<0.01)$

a, b, c; Aynı satırda ayrı harflerle gösterilen ortalamalar farklıdır $(P<0.05)$

birbirlerinden çok ónemli derecede farklı bulunmuştur $(P<0.01)$. Karkas randımanı bakımından 3. grup $(\% 68.17 \pm 0.90)$ 2. $(\% 71.05 \pm 0.94)$ ve 1. $(\% 71.21 \pm 0.63)$ gruptan önemli dazeyde daha dâşak değerler sağlamıştır. Etlik piliç yetiştiriciliğinde pek istenmeyen özelliklerden olan abdominal yağ bakımından en yüksek karın yağı oranı 1. gruptan $(1,15 \pm 0.08)$ elde edilirken, bunu 2 . $(1.07 \pm 0.12)$ ve $3 .(1.07 \pm 0.08)$ grup izlemiştir $(P>0.05)$. Yenilebilir iç organlar oranı \%100 EMYÜ $(\% 5.06 \pm 0.50)$ kullanıminda kontrole göre $(\% 4.17 \pm 0.08)$ onemli derecede artarken $(P<0.05)$, \%50 EMYÜ $(\% 4.11 \pm 0.09)$ kullanımında ise sayısal olarak düşmüștür $(P>0.05)$. Yenilebilir iç organlar oranının \%100 EMYÜ ile artmış olmasında taşlık ağırlığının etkisi olabilir. Zira, en yăksek taşlık oranı 3. gruptan elde edilmiş $(\% 1.75)$ bunu 2 . grup $(\% 1.62)$ ve 1. grup $(\% 1.54)$ izlemiştir. Tașlık oranları bakımından 1. ve 3 , grup arasındaki farklılık çok önemli bulunmuştur $(P<0.01)$. Bu durum ise 3 . gruptaki hayvanların çok ince formdaki EMYÜ yerine (seçerek) daha çok iri partiküllu hammaddeleri tüketmeleri ile açıklanabilir. Çok ince formdaki yemler kanat/ı hayvanların taşlıklarında atrofilere neden olmakta bu ise kas tembelliğine yol açmaktadır (Cumming, 1994).

Şehu ve ark. (1997), erkek bildircınlarda karkas ağılığının ve karkas randımanının ekmek mayası ilavesi ile düştağana beliriemişlerdir. Karmalarda \%20'ye kadar ekmek mayası bulunmasının etin kalitesi azerine olumsuz bir etkisinin olmadığı saptanmıştır (Yalçın ve ark., 1998). Bu çalıșmada da duyusal analizler yapılmamış olmakla beraber tōketicilerden hayvanların lezzetleri ile ilgili herhangi bir şikayet gelmemiştir.

\section{Maliyet unsurları}

Gruplara ait kimi maliyet unsuriarı Çizelge $5^{\prime}$ de verilmiştir.

Çizelge 5 incelendiğinde karmalar içinde birim yem fiyatı ve toplam yem maliyeti bakımından \%100 EMYU kullanılan 3. karmanın diğer gruplara gơre daha düşük maliyet taşımaktadır. Bununla birlikte, canlı ağırlık artışı başına yem maliyeti ile kilogram karkas maliyeti dikkate alındığında 3. Karmanın bu avantajı dezavantaja

Çizeige 5. Gruplara ait kimi maliyet unsurları

\begin{tabular}{|l|c|c|c|}
\hline M.Unsurlari & 1. Grup & 2. Grup & 3. Grup \\
\hline YF & 0.234 & 0.223 & 0.203 \\
\hline HTYM & 1.031 & 1.006 & 0.895 \\
\hline CAAYM & 0.452 & 0.473 & 0.524 \\
\hline KM & 0.622 & 0.653 & 0.745 \\
\hline
\end{tabular}

M:Maliyet, YF: Yem fiyati, \$ / kg yem; HTYM: Hayvan bașina topiam yem maliyeti, \$/ kg yem / hayvan; CAAYM: Canli ağırlik artışı bașına yem maliyeti, \$/ kg yem / kg CAA, KM: karkas maliyeti, \$ / $\mathrm{kg}$ karkas 
dönüşmektedir. Bu sonuçlar karmaya SK'nın sağladığı proteinin $\% 50$ ve $\% 100$ '0 oraninda EMYÜ proteini ikamesinin daha önemli maliyet unsurları (CAAYM ve KM) üzerine olumsuz etkilerde bulunmaktadır.

\section{Sonuç}

Etlik piliç karmalarında SK yerine $\% 50 \quad(0-21$. günlerde karmada yaklaşık $\% 13,21-42$. günlerde $\% 10$ ) ve $\% 100(0-21$. günlerde $\% 26,21-42$. günlerde $\% 20)$ EMYÜ kullanılması CA, CAA, karkas ağırığı ve karkas randımanını olumsuz yönde etkilerken, yem taketimi üzerine etkisi olmamıştır. YDS üzerine SK yerine $\% 50$ EMYÜ däzeyinin 21-42. günlerde, $\% 100$ düzeyinin ise bütün dönemlerde olumsuz etkisi olmuştur.

\section{Kaynaklar}

Akyıldız, A, R. 1984. Yemler Bilgisi Laboratuvar Klavuzu. Ankara Üniv. Zir. Fak. Yay. No:895, Ankara Üniv, Basimevi, 236 s.

Atay, D. ve M. Erdem, 1972. Melas mayasının kasaplik civciv rasyonlarında soya klspesi yerine protein kaynaği olarak değerlendirilmesine ilișkin araştırmalar. AÜZF Yılliğı 22(1-2) 202-217.

Cumming, R. B. 1994. Opportunities for whole grain feeding. Proceedings of the $9^{\text {th }}$ European Poultry Conference, Vol:2, World Poultry Sci. Assc. s:119-122.

Ergül, M. 1975. Pamuk tohumu küspesinin broiler karmalarında kullanma imkanları. III. Esası mısır olan broiler karmalarında ñinuk tohumu küspesini melas ispirto mayası (Saccharomyces cerevisiae) ile takviye imkanları. EÜZF Derg., 49:3-9.

Gunzel, D. and H. Vogt, 1982. Yeast grown on whey in poultry rations. 2. Landbauforschung volkenrode, 32(1) 16-18.

Koca, Y. 1998. Dünya'da ve Türkiye'de yem sanayiinin durumu. 4. Uluslararasi Yem Kongresi ve Yem Sergisi, 45 Mayıs, Kapadokya, Turkiye Yem Sanayicileri Birliği, s:9-26.

NRC, 1984. (National Research Council), Nutrient Requirement of Poultry. $8^{\text {th }}$ Revised Edition, National Academy Press, Washington, D.C.

Özen, N., A. Çakır, S. Haşimoğlu ve A. Aksoy, 1981. Yemler (Teksir). Atatürk. Univ. Zir. Fak., Erzurum.
Özen, N. 1989. Tavukçuluk. Yetiștirme, Islah, Beslenme, Hastalıklar, Et ve Yumurta Teknolojisi. 2. Tipkı Basım, Ondokuz Mayıs Oniv. Yayın No:48, Samsun.

Öztürk; E. ve N. Özen, 1994. Şarapçillık Artığı Maya Tortusunun Etlik Piliç ve Yumurta Tavuğu Rasyonlarında Kullanılabilme Olanakları. Tr. J. of Veterinary and Anim. Sci. 18 (5): 251-257

Sarı, 0. 1976. Kümes hayvanları karmalarında soya küspesi yerine melas mayası kullanma olanakları üzerinde araştırmalar. EÜZF Derg., 13(1), 27-36.

Sarı, O., N. Asyalı, F. Sevgican ve Ş. Bulgurlu, 1978. Kasaplık piliç bitiş karmalarında soya küspesi yerine melas mayası kullanma olanakları. EÜZF Derg., 15(2), 209-217.

SPSS, 1994. Statistical Package for Social Science for Windows Release 6.0. SPSS Inc.

Surdjiiska, S., B. Marinov and D. Tomova, 1987. Mixed feeds for broiler chickens with different amounts of fodder yeast. Zhitnov'dni Nauki, 24 (1), 47-52.

Şehu, A., S. Yalçın ve F. Karakaş, 1997. Bıldırcın rasyonlarına katılan ekmek mayasınin performans ve karkas randimanina etkisi. Doga-Tr. J. of Veterinary and Animal Sciences 21:221226.

Valdivie, M. 1975. Saccharomyces yeast as a by-product from alcohol production on final molasses in diets for broilers. Cuban J.of Agricultural Science, 9 (3), 327-331.

Virk, R. S., J. S. Chawla and G. S. Makkar, 1989. Evaluation of dried inactivated yeast as a substitute of fish meal broiler mashes, Indian J. of Poultry Sci., 24 (3) 216-222.

Yalçın, S., A. G. Önol, D. Koçak ve I. Özcan, 1993. Ekmek mayasının broyler rasyonlarında protein kaynağı olarak kullanilmasi. Doğa-Tr. J. of Veterinary and Animal Sciences, 17:305-309.

Yalçın, S., S. Yalçın ve D. Koçak, 1998. Broyler rasyoniarına katılan ekmek mayasının et kalitesi üzerine etkileri. 4. Uluslararası Yem Kongresi ve Yem Sergisi, 4-5 Mayıs, Kapadokya, Türkiye Yem Sanayicileri Birliği, s:231-236.

Yalcin, S. ve A. G. Onol, 1999. Ekmek mayasinin broyler ve yumurta tavuğu rasyonlarında kullanımı. Yutav'99 Uluslararası Tavukçuluk Fuarı ve Konferansı, s: $441-448$, 3-6 Haziran, Istanbul.

Yeldan, M. ve I. Çiftçi, 1993. Tavuklarda yem seçimi ve yemin fiziksel yapısinin etkileri. Yem Magazin, Yil:1, Sayı:3, Sayfa: 18-20. 